\title{
Ground-Water Quality of Alluvial and Sedimentary-Rock Aquifers in the Vicinity of Fairplay and Alma, Park County, Colorado, September-October 2002
}

\author{
By Roderick F. Ortiz
}

\section{Introduction}

Park County is one of the fastest growing counties in Colorado. Located southwest of Denver (fig. 1), the predominantly rural county has experienced a substantial increase in development as commuter communities and vacation homes continue to be built in the county. Health department officials, planners, and County Commissioners in Park County are interested in obtaining information regarding water quality in aquifers that serve the residents of the county. Of particular interest is the potential degradation of ground-water quality due to the increasing number and density of individual sewage disposal systems (ISDS). In 2000, the U.S. Geological Survey (USGS), in cooperation with Park County, began a study to evaluate ground-water quality in the various aquifers in Park County that supply water to domestic wells. This report summarizes the ground-water quality of samples collected in September or October 2002 from domestic wells completed in alluvial and sedimentary-rock aquifers in the vicinity of Fairplay and Alma, Colo. (fig. 1). Additionally, this report provides an initial assessment of the potential effects of ISDSs on ground-water quality in sedimentary-rock aquifers in the vicinity of Fairplay and Alma, Colorado.

Water samples were collected from 53 domestic wells during September and October of 2002; 13 of the wells were completed in alluvial aquifers, and 40 were completed in sedimentary-rock aquifers. Measurements of $\mathrm{pH}$, specific conductance, and bacteria were conducted in the field, and water samples were collected following procedures described in USGS National Field Manual (Wilde and others, 1998). Water samples were analyzed for various chemical groups including major ions, nitrogen species, phosphorus species, selected trace metals, and radiochemical constituents (Fishman, 1993). Additionally, water samples at selected wells were analyzed for an extensive list of organic chemicals that are indicative of contamination from ISDS effluent (Zaugg and others, 2002). Analyses of these samples were done at the USGS National Water Quality Laboratory in Denver, Colo. Water samples from selected wells also were analyzed for tritium and analyzed at the USGS Chlorofluorocarbon Laboratory in Reston, Virginia. Quality-control samples collected in the field included two blank and five replicate samples. Results indicate that field procedures did not contaminate the environmental samples. Data used in this analysis can be obtained on the Web at URL http://waterdata.usgs.gov/co/nwis/qwdata

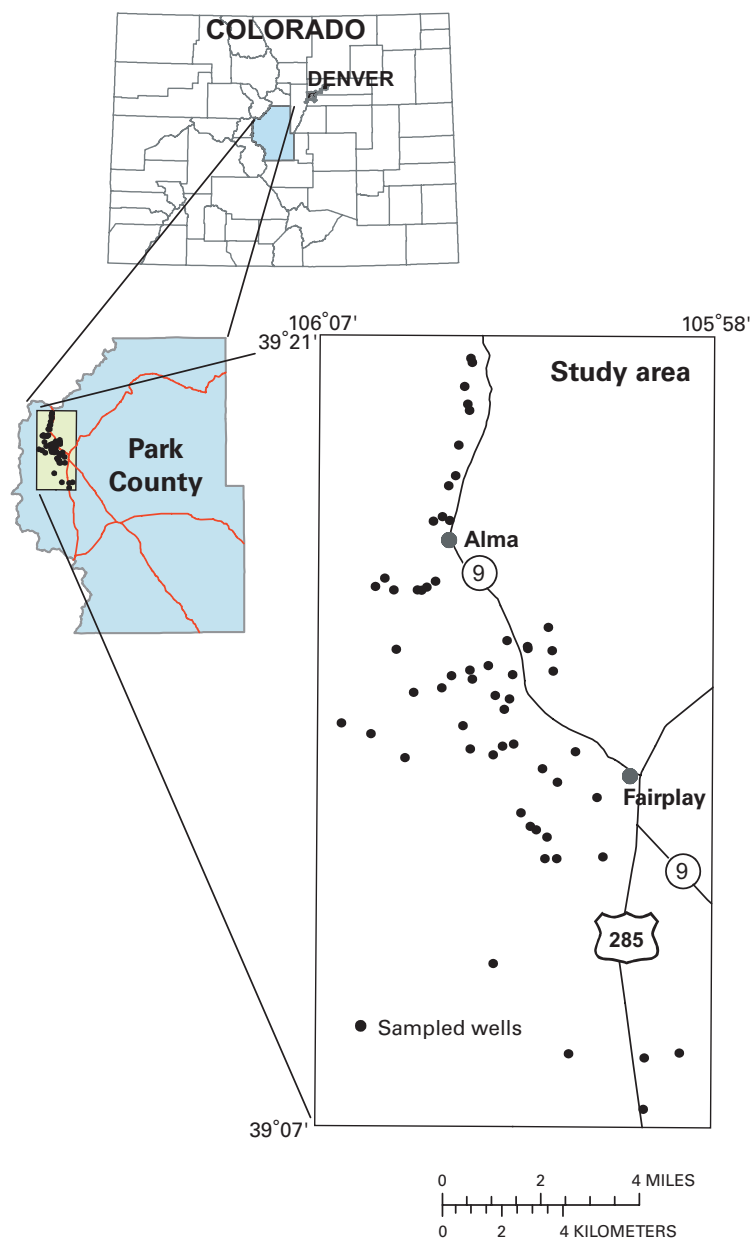

Figure 1. Map showing location of study area.

(search on Park County, data type ground water, and the date range of September 1 through October 31, 2002).

The geology of the study area consists of unconsolidated alluvial deposits of Quaternary age which compose alluvial aquifers that contain water in the void spaces between the grains of sand and gravel that make up the deposits, and sedimentary rocks of Tertiary and Paleozoic age which compose sedimentary-rock aquifers that contain water in the pore spaces of the various sedimentary layers and in the fractures that cut across 
the sedimentary-rock layers (Tweto, 1979). Reported well yields for wells in the vicinity of Fairplay, Colo., range from less than 1 gallon per minute $(\mathrm{gal} / \mathrm{min})$ to more than $200 \mathrm{gal} / \mathrm{min}$. The variability in well yields depends on many things, including the type of geologic material the well is completed in (alluvial or sedimentary), the number of fractures intercepted by a well, the degree of openness of those fractures, the percentage of pore spaces (porosity), the interconnectedness of pores containing water (permeability), and the length of the open interval of the well (fig. 2). Well yields for sampled wells in the alluvial aquifers ranged from 5 to $15 \mathrm{gal} / \mathrm{min}$, and well yields for sampled wells in the sedimentary-rock aquifers ranged from 2 to $15 \mathrm{gal} / \mathrm{min}$. Depths for wells chosen for sampling ranged from 50 to 305 feet (ft). The well yields and depths for the wells sampled are representative of most of the wells drilled in the various aquifers in the vicinity of Fairplay, Colo. (Colorado Division of Water Resources, 2000). There was no correlation between the concentration of the various chemicals sampled as part of this study and the well depths or yields.

The amount of time it takes for water to recharge the aquifer and reach the wells varies with the openness and connectedness of fractures and pore spaces, the distance from the recharge point to the open interval of a well, and the velocity of water flow in the fractures or pore spaces. Because the rate of recharge and the flow velocity in the vicinity of each well can vary, it is not known whether ISDS effluent can reach the ground water before chemical and biological contaminants are reduced in concentration or are removed from the effluent by geochemical and physical processes.

This report provides a general assessment of ground-water quality and an initial assessment of whether contamination of ground water has occurred. The closeness of neighboring wells and ISDSs varies depending on the size of the lots in each development. Each residence has its own ISDS. House densities range from several houses per acre to a single house on many acres. Hypothetically, there is a greater potential for degradation

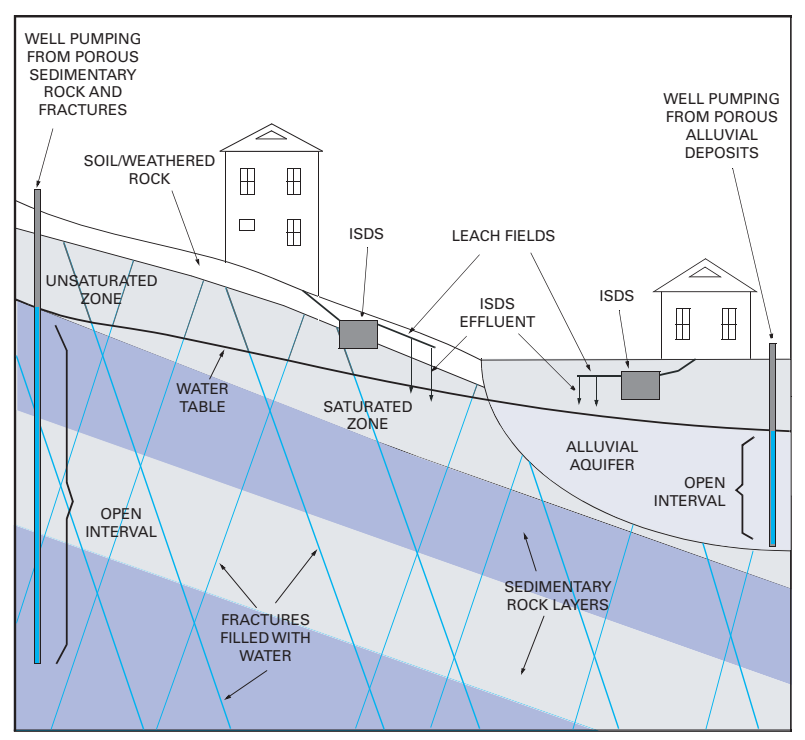

Figure 2. Diagram showing the relation of Individual Sewage Disposal Systems (ISDS), domestic wells, and the water table in an alluvial and a fractured-rock ground-water system. of ground-water quality as houses are built closer to each other and as the density of ISDSs increases.

\section{General Assessment of Ground-Water Quality}

Generally, the water quality was similar in samples collected from the alluvial and sedimentary-rock aquifers (table 1). The median $\mathrm{pH}$ value and dissolved-solids concentration for both types of aquifers were 7.7 standard units and 219 milligrams per liter (mg/L), respectively. Median hardness concentrations for both aquifer types were $210 \mathrm{mg} / \mathrm{L}$, which would be considered "very hard" water (Hem, 1985). The maximum hardness concentration of $1,600 \mathrm{mg} / \mathrm{L}$ was measured from a sample collected from a well completed in the sedimentary-rock aquifer. The maximum hardness concentration measured from samples collected from wells completed in the alluvial aquifer was $350 \mathrm{mg} / \mathrm{L}$. The median alkalinity concentration in samples collected from both aquifers was $180 \mathrm{mg} / \mathrm{L}$. Alkalinity is a measure of the ability of the water to neutralize acids. Trace-metal concentrations generally were small and similar to concentrations in samples collected from 1962 to 1998 in Park County (Kimbrough, 2001). The median boron concentration for both aquifer types was reported as less than the reporting limit of 13 micrograms per liter $(\mu \mathrm{g} / \mathrm{L})$. The median dissolved-radon concentration for samples collected from both aquifer types was 1,600 picocuries per liter $(\mathrm{pCi} / \mathrm{L})$; however, the range in concentrations for the alluvial wells was 990 to $2,400 \mathrm{pCi} / \mathrm{L}$, whereas the range in concentrations for the wells completed in the sedimentary-rock aquifers was 50 to $6,000 \mathrm{pCi} / \mathrm{L}$.

Dissolved organic carbon concentrations from either aquifer type generally were less than $1 \mathrm{mg} / \mathrm{L}$. Total coliform bacteria were detected in only one well and there were no detections of Escherichia coli (E. coli) bacteria; total coliform and E. coli can originate from humans and other warm-blooded animals. Isophorone was the only organic chemical reported at a concentration above the reporting limit for a specific compound. The concentration of isophorone in the sample from one well completed in the sedimentary-rock aquifer was $3.3 \mu \mathrm{g} / \mathrm{L}$. Isophorone is an industrial chemical used as a solvent in some printing inks, paints, lacquers, and adhesives. It also is used as an intermediate in the production of certain chemicals, and it occurs naturally in cranberries (Agency for Toxic Substances and Disease Registry, 1989).

Data collected as part of this study were compared to primary drinking-water standards (U.S. Environmental Protection Agency, 2002) to assess the general quality of the water in the study area for domestic use. Although the primary drinkingwater regulations only apply to public water systems, these standards are used here as a basis for comparing how water-quality results from well samples compare to standards. Nitrite concentrations in all samples were reported as less than the reporting limit of $0.008 \mathrm{mg} / \mathrm{L}$, which is below the primary standard of $1 \mathrm{mg} / \mathrm{L}$ reported as nitrogen. Because nitrite concentrations were low, comparisons to the nitrate standard were done using nitrite plus nitrate data. The maximum nitrite plus nitrate concentration was $4.5 \mathrm{mg} / \mathrm{L}$, which was much less than the $10 \mathrm{mg} / \mathrm{L}$ standard for nitrate (reported as nitrogen) set by the U.S. Environmental Protection Agency. Additionally, the standard for fluoride $(4 \mathrm{mg} / \mathrm{L})$ was not exceeded in any sample. Proposed standards for arsenic $(10 \mu \mathrm{g} / \mathrm{L})$ and current standards 
Table 1. Summary of water-quality data collected from domestic wells installed in alluvial or sedimentary-rock aquifers, September-0ctober 2002.

[mg/L, milligrams per liter; col, colonies; <, less than; $\mathrm{mL}$, milliliters; $\mathrm{CaCO}_{3}$, calcium carbonate; $\mathrm{N}$, nitrogen, $\mu \mathrm{g} / \mathrm{L}$, micrograms per liter; ---, not calculated, only one data value available; pCi/L, picocuries per liter]

\begin{tabular}{|c|c|c|c|c|c|c|c|c|c|}
\hline \multirow[b]{2}{*}{$\begin{array}{l}\text { Measurement value or chemical } \\
\text { concentration (units) }\end{array}$} & \multicolumn{4}{|c|}{ Alluvial aquifer } & \multicolumn{4}{|c|}{ Sedimentary-rock aquifer } & \multirow{2}{*}{$\begin{array}{l}\text { Median } \\
\text { value } \\
\text { for both } \\
\text { aquifer } \\
\text { types }\end{array}$} \\
\hline & $\begin{array}{c}\text { Number } \\
\text { of } \\
\text { samples }\end{array}$ & Minimum & Median & Maximum & $\begin{array}{c}\text { Number } \\
\text { of } \\
\text { samples }\end{array}$ & Minimum & Median & Maximum & \\
\hline $\mathrm{pH}$ (standard units) & 13 & 7.4 & 7.6 & 8.1 & 40 & 7.2 & 7.7 & 8.1 & 7.7 \\
\hline $\begin{array}{l}\text { Solids, dissolved, } \\
\text { sum of constituents (mg/L) }\end{array}$ & 13 & 123 & 209 & 408 & 40 & 106 & 221 & 2,110 & 219 \\
\hline Total coliform (col/ $100 \mathrm{~mL})$ & 13 & $<1$ & $<1$ & 5 & 40 & $<1$ & $<1$ & $<1$ & $<1$ \\
\hline Escherichia coli $(\mathrm{col} / 100 \mathrm{~mL})$ & 13 & $<1$ & $<1$ & $<1$ & 40 & $<1$ & $<1$ & $<1$ & $<1$ \\
\hline Dissolved organic carbon (mg/L) & 5 & 0.5 & 0.5 & 0.8 & 20 & $<0.3$ & 0.4 & 1.1 & 0.5 \\
\hline Hardness (mg/L) & 13 & 120 & 200 & 350 & 40 & 100 & 210 & 1,600 & 210 \\
\hline Alkalinity $\left(\mathrm{mg} / \mathrm{L}\right.$ as $\left.\mathrm{CaCO}_{3}\right)$ & 13 & 110 & 162 & 243 & 38 & 91 & 193 & 374 & 180 \\
\hline Chloride, dissolved (mg/L) & 13 & .3 & 1.1 & 6.4 & 40 & .3 & 1.2 & 8.6 & 1.2 \\
\hline Fluoride, dissolved (mg/L) & 13 & $<.17$ & $<.17$ & .20 & 40 & .10 & .20 & .50 & .20 \\
\hline Sulfate, dissolved (mg/L) & 13 & 3.5 & 21.0 & 150 & 40 & 2.9 & 21.2 & 1,380 & 21.0 \\
\hline Nitrite, dissolved, as N (mg/L) & 13 & $<.008$ & $<.008$ & $<.008$ & 40 & $<.008$ & $<.008$ & $<.008$ & $<.008$ \\
\hline $\begin{array}{l}\text { Nitrite plus nitrate, dissolved, } \\
\text { as } \mathrm{N}(\mathrm{mg} / \mathrm{L})\end{array}$ & 13 & $<.05$ & .15 & 4.5 & 40 & $<.05$ & .08 & .54 & .10 \\
\hline Phosphorus, dissolved (mg/L) & 13 & $<.004$ & $<.004$ & .069 & 40 & $<.004$ & $<.004$ & .053 & $<.004$ \\
\hline Aluminum, dissolved $(\mu \mathrm{g} / \mathrm{L})$ & 1 & --- & $<15$ & --- & 6 & $<15$ & $<15$ & $<15$ & $<15$ \\
\hline Arsenic, dissolved $(\mu \mathrm{g} / \mathrm{L})$ & 1 & --- & $<1.9$ & --- & 6 & $<1.9$ & 2.0 & 3.0 & $<1.9$ \\
\hline Boron, dissolved ( $\mu \mathrm{g} / \mathrm{L})$ & 13 & $<13$ & $<13$ & 72 & 40 & $<13$ & $<13$ & 453 & $<13$ \\
\hline Cadmium, dissolved $(\mu \mathrm{g} / \mathrm{L})$ & 1 & --- & $<8.0$ & --- & 6 & $<8.0$ & $<8.0$ & $<8.0$ & $<8.0$ \\
\hline Copper, dissolved $(\mu \mathrm{g} / \mathrm{L})$ & 1 & --- & $<6.0$ & --- & 6 & $<6.0$ & $<6.0$ & 10 & $<6.0$ \\
\hline Iron, dissolved ( $\mu \mathrm{g} / \mathrm{L})$ & 1 & --- & 190 & --- & 6 & $<10$ & 192 & 810 & 190 \\
\hline Manganese, dissolved $(\mu \mathrm{g} / \mathrm{L})$ & 1 & --- & 15 & --- & 6 & $<2$ & 11 & 31 & 14 \\
\hline Zinc, dissolved $(\mu \mathrm{g} / \mathrm{L})$ & 1 & --- & $<24$ & --- & 6 & $<24$ & $<24$ & 320 & $<24$ \\
\hline Uranium, dissolved $(\mu \mathrm{g} / \mathrm{L})$ & 5 & 9 & 3.0 & 6.0 & 14 & .7 & 3.3 & 9.6 & 3.0 \\
\hline $\begin{array}{l}\text { Radon, dissolved, as } \\
\text { Radon-222 (pCi/L) }\end{array}$ & 5 & 990 & 1,700 & 2,400 & 14 & 50 & 1,550 & 6,000 & 1,600 \\
\hline Tritium $(\mathrm{pCi} / \mathrm{L})$ & 4 & 2.0 & 36.5 & 49 & 5 & $<2.5$ & 23 & 38 & 35 \\
\hline Isophorone $(\mu \mathrm{g} / \mathrm{L})$ & 2 & $<.5$ & $<.5$ & $<.5$ & 5 & $<.5$ & $<.5$ & 3.3 & $<.5$ \\
\hline
\end{tabular}


for copper $(1,300 \mu \mathrm{g} / \mathrm{L})$ were not exceeded. All cadmium concentrations were reported as less than $8 \mu \mathrm{g} / \mathrm{L}$; however, a direct comparison to the standard could not be made because the current standard for cadmium is $5 \mu \mathrm{g} / \mathrm{L}$.

Primary drinking-water standards have been established for some radionuclides (U.S. Environmental Protection Agency, 2002). Radioactive elements sampled as part of this study included uranium and radon. Drinking-water standards have been established for uranium because of increased risk of cancer and kidney toxicity. The current standard (2004) of $30 \mu \mathrm{g} / \mathrm{L}$ was not exceeded in any sample analyzed for uranium. Radon in ground water that is used for domestic purposes is a concern because of increased risk of lung cancer (off-gassing) and stomach cancer (ingestion). Currently (2004), there is no federally enforced drinking-water standard for radon in community water-supply systems, but proposed regulations suggest levels of 300 or 4,000 pCi/L (U.S. Environmental Protection Agency, 1999). The varying levels are dependent on other mitigating remedial activities. The proposed standards do not pertain to private wells. Radon may be of concern because the median radon concentration was $1,600 \mathrm{pCi} / \mathrm{L}$ for the 19 wells sampled.

Secondary drinking-water standards also have been defined for common chemicals that can change the aesthetic characteristics of water such as taste, odor, or color (U.S. Environmental Protection Agency, 2002). The secondary standard for chloride (250 mg/L) was not exceeded in any sample. About 6 percent of the sulfate concentrations exceeded the secondary standard of $250 \mathrm{mg} / \mathrm{L}$; the maximum sulfate concentration was $1,380 \mathrm{mg} / \mathrm{L}$. All sulfate concentrations greater than $250 \mathrm{mg} / \mathrm{L}$ were associated with wells completed in the sedimentary-rock aquifers. Aluminum concentrations were below the reporting limit of $15 \mu \mathrm{g} / \mathrm{L}$ and the secondary standard of $50 \mu \mathrm{g} / \mathrm{L}$. Zinc concentrations generally were below the reporting limit of $24 \mu \mathrm{g} / \mathrm{L}$ and the secondary standard of $5,000 \mu \mathrm{g} / \mathrm{L}$. Iron and manganese concentrations were more often reported above the reporting limit. No manganese sample exceeded the secondary standard of $50 \mu \mathrm{g} / \mathrm{L}$. Three of six samples collected in the sedimentary-rock aquifers exceeded the secondary standard of $300 \mu \mathrm{g} / \mathrm{L}$ for iron.

Nine tritium samples were collected to attempt to determine an approximate age, or time since recharge, of the ground water pumped by wells: four samples were collected from wells completed in the alluvial aquifers, and five samples were collected from wells completed in the sedimentary-rock aquifers. Tritium is used as an age-dating tracer because it was produced in relatively high concentrations as a result of atmospheric nuclear bomb testing beginning in 1954 (Kendall and McDonnell, 1998). Concentrations of tritium do not definitively yield the age of the water in a sample but must be used with other age-dating chemicals to refine the age estimate. Ground water having a certain tritium concentration is likely to contain a mixture of waters of different ages that exhibit a composite age based on the proportions of different-age waters contributing to a sample. Concentrations greater than $10 \mathrm{pCi} / \mathrm{L}$ indicate that recharge to the ground-water system occurred after 1954 (Kendall and McDonnell, 1998). Tritium concentrations ranged from 19 to 49 picocuries per liter in seven of the nine samples, which included samples collected from both aquifer types. One sample from each aquifer type had tritium concentrations at or near the reporting limit of $2.5 \mathrm{pCi} / \mathrm{L}$, which indicated that water collected from these wells predates 1954. Additional data analysis of the age-dating chemicals is needed to evaluate the age of ground water and the vulnerability of the ground water to contamination.

\section{Potential Effects of Individual Sewage Disposal System Effluent on Ground-Water Quality}

Geochemical and physical processes occur in the subsoilunsaturated zone above the water table and the saturated zone below the water table (fig. 2) - that can reduce the concentrations of chemical and biological constituents in ISDS effluent. For a properly functioning ISDS, most of the potential contaminants in effluent are removed by filtration or oxidation in the unsaturated zone below the leach field and above the water table (Wilhelm and others, 1994). When effluent reaches the unsaturated zone above the water table, it flows through the pores between the particles, such as sand and gravel from the weathered sedimentary rock, that make up the subsoil. Large particles and bacteria in the effluent can be filtered by the subsoil, leaving mostly dissolved compounds in the effluent. As the effluent flows through the subsoil and is exposed to oxygen, ammonia is oxidized to form nitrate (nitrite plus nitrate, as nitrogen). When nitrate reaches the water table, and if dissolved organic carbon is present and dissolved oxygen is absent, the nitrate and dissolved organic carbon may be consumed by denitrifying bacteria to produce nitrogen and carbon dioxide gasses. Thus, the concentration of nitrate increases beyond the leach field but then can decrease as it travels through the saturated zone (Robertson and others, 1989).

Caffeine and other organic chemicals can be degraded to other compounds by bacteria in the saturated zone in the vicinity of the leach field from which the chemicals originated. However, organic chemicals can persist in ground water if degrading bacteria are not present.

Biological constituents in ISDS effluent that can cause disease (pathogenic organisms) include bacteria and viruses. These microorganisms have different survival rates and transport properties in the unsaturated and saturated zones below a leach field. For example, E. coli can potentially survive for several weeks in the subsurface if conditions are favorable (Matthess and Pekdeger, 1981). It is not known whether E. coli can survive long enough in a fractured-rock setting to be transported to the water table and eventually to wells. Total coliform and E. coli bacteria can be removed from ISDS effluent by filtration as the effluent flows through the unsaturated zone (Viraraghavan and Warnock, 1976). If the water table lies close to the land surface, however, the unsaturated zone is thin and more of the bacteria in the effluent can potentially reach the ground water (Canter and Knox, 1985).

\section{Indicators of Ground-Water Contamination from Individual Sewage Disposal Systems}

Samples collected from wells were analyzed for selected chemicals and bacteria that can originate from ISDSs, however, many of these chemicals and bacteria also can enter the ground water from natural sources. Chemicals and bacteria originating from natural sources usually do not occur at elevated concentrations because they come from dispersed sources such as waste from warm-blooded animals, decomposition of forest material, 
deposition from the atmosphere, or from decomposition of rocks. Whether from ISDSs or natural sources, elevated concentrations of chemicals or bacteria can indicate degraded groundwater quality. An ISDS can provide a focused source of these chemicals and bacteria if the leach-field pipe is too close to the water table or if the ground-water flow velocity is too rapid to allow for proper geochemical or physical treatment of the ISDS effluent. Chemicals from products that are used in households can enter the ground-water system as a more concentrated effluent from an ISDS (Kolpin and others, 2002) than from natural sources. Examples of products containing these chemicals include soaps containing boron, dietary salt containing chloride, caffeinated beverages, pesticides, perfumes, or human waste containing nitrate, nitrite, and ammonia. Persistent detections or elevated concentrations of bacteria also may indicate contamination from an ISDS, but bacteria such as total coliform and $E$. coli can originate from other warm-blooded animals as well as humans.

\section{Potential Indications of Contamination from Individual Sewage Disposal Systems}

Generally, most chemicals associated with ISDS contamination were not detected in the water samples collected during this study. However, quantification of even small concentrations of bacteria and chemicals associated with ISDS effluent can indicate a potential for contamination. Only one sample had detectable concentrations of total coliform bacteria, and none of the 43 ground-water samples analyzed had detectable concentrations of E. coli. Boron was detected in 23 percent of the samples collected from wells completed in the alluvial aquifer and in 27 percent of the samples collected from wells completed in the sedimentary-rock aquifer. Only one of the seven samples analyzed for selected organic chemicals associated with contamination from human activities had detectable concentrations of an organic chemical. Isophorone was reported at $3.3 \mu \mathrm{g} / \mathrm{L}$ in a sample collected from well completed in a sedimentary-rock aquifer. D-limonene, methylene-blue active substances, 4-tert-octylphenol, and bisphenol-A were detected in one sample each at trace concentrations. Para-nonylphenol and phenol were detected at trace concentrations in two samples each. D-limonene is a citrus degreaser and methylene-blue active substances are used in surfactants or detergents. Phenols are used primarily in the formation of phenolic resins and in the manufacture of nylon and other synthetic fibers. Phenols also are used in slimicides (chemicals that kill bacteria and fungi in slimes), disinfectants, antiseptics, and medicinal preparations such as mouthwash and throat lozenges. Although the presence of these organic chemicals could indicate contamination from ISDSs, the extent of the contamination was limited to mostly trace-level detections.

\section{Sample Plan to Compare Individual Sewage Disposal System Densities}

The overall sampling plan was designed, in part, to allow an evaluation of whether the density of development (proximity of wells and ISDSs) was a significant factor in potential degradation of ground-water quality. The density of private wells was used as a surrogate for the density of ISDSs because those lots that have a well and a house also have an ISDS, and records for wells are more easily accessible than records of ISDSs. Thus, well density based on information obtained from Colorado Division of Water Resources (2000) was assumed to be equivalent to ISDS density for the purposes of this analysis. Only wells installed in sedimentary-rock aquifers were evaluated for differences in density categories because the number of samples collected in each ISDS density category associated with the alluvial aquifers was small. The 40 wells installed in sedimentary-rock aquifers wells were divided into 4 density categories based on the number of wells per acre. The high-density category (10 wells) consisted of more than 1 well per acre. The medium-density category (12 wells) consisted of 1 well in 3 acres. The low-density category (14 wells) consisted of 1 well in 5 or more acres. Finally, the four background wells were not expected to be influenced by other wells and ISDSs.

\section{Potential Effects of Individual Sewage Disposal System Density on Ground-Water Quality}

The data were grouped by ISDS density category. Wilcoxson rank-sum tests (Helsel and Hirsch, 1992) were run to determine whether a statistical difference exists between constituents for any combination of two density categories. Differences between data sets were determined to be significant when the $p$-value was 0.05 or smaller. A $p$-value of 0.05 means that there is a 95-percent confidence that two data sets being compared are different. As the $p$-value increases, the level of confidence that two data sets are different decreases.

Comparisons using Wilcoxon rank-sum tests did not identify significant differences between ISDS density categories for any constituent with the exception of phosphorus. Significant differences for phosphorus were observed between the high-density category and both the low-density category and the background wells. Medians for the low-density category and the background wells were higher than the median for samples from the high-density category. Phosphorus concentrations in samples collected from the high-density category wells were all reported as less than the reporting limit. Overall, the data did not indicate major effects of ISDS on ground-water quality.

\section{References}

Agency for Toxic Substances and Disease Registry, 1989, Public health statement for Isophorone, accessed March 17, 2004, at http://www.atsdr.cdc.gov/toxprofiles/phs138.html.

Canter, L.W., and Knox, R.C., 1985, Septic tank system effects on ground water quality: Chelsea, Mich., Lewis Publishers, $336 \mathrm{p}$.

Colorado Division of Water Resources, 2000, Public well records available from the Division of Water Resources Records Section, Denver, Colo.

Fishman, M.J., ed., 1993, Methods of analysis by the U.S. Geological Survey National Water Quality LaboratoryDetermination of inorganic and organic constituents in water and fluvial sediments: U.S. Geological Survey Open-File Report 93-125, 217 p. 
Helsel, D.R., and Hirsch, R.M., 1992, Statistical methods in water resources: N.Y., Elsevier Science Publishing Company, Inc., 522 p., 1 diskette.

Hem, J.D., 1985, Study and interpretation of the chemical characteristics of natural water: U.S. Geological Survey WaterSupply Paper 2254, 263 p.

Kendall, C., and McDonnell, J.J., eds., 1998, Isotope tracers in catchment hydrology: N.Y., Elsevier Science Publishing Company, Inc., 839 p.

Kimbrough, R.A., 2001, Review and analysis of available streamflow and water-quality data for Park County, Colorado, 1962-98: U.S. Geological Survey Water-Resources Investigations Report 01-4034, 66 p.

Kolpin, D.W., Furlong, E.T., Meyer, M.T., Thurman, E.M., Zaugg, S.D., Barber, L.B., and Buxton, H.T., 2002, Pharmaceuticals, hormones, and other organic wastewater compounds in U.S. streams, 1999-2000- A national reconnaissance: Environmental Science and Technology, v. 36, n. 6 , p. $1202-1211$.

Matthess, G., and Pekdeger, A., 1981, Survival and transport of pathogenic bacteria and viruses in ground water, in Proceedings, First International Conference on Ground-Water-Quality Research, Houston, Texas, John Wiley and Sons, N.Y., p. 472-482.

Robertson, W.D., Sudicky, E.A., Cherry, J.A., Rappaport, R.A., and Shimp, R.J., 1989, in Kobus, H.E., and Kinzelbach, W., eds., Impact of a domestic septic system on an unconfined sand aquifer: Proceedings of the international symposium on contaminant transport in ground water, Stuttgart, Federal Republic of Germany, April 4-6, 1989, v. 3, p. 105-112.
Tweto, Ogden, comp., 1979, Geologic map of Colorado: U.S. Geological Survey State Geologic Map, scale 1:500,000 (reprinted).

U.S. Environmental Protection Agency, 1999, National primary drinking water regulations- Radon-222, proposed rule: Code of Federal Regulations, v. 64, Title 40, chap. 1, part 141 and part 142, p. 59246-59344.

U.S. Environmental Protection Agency, 2002, National primary drinking water regulations: Code of Federal Regulations, v. 64 , Title 40, chap. 1, part 141 and part 143.2.

Viraraghavan, T., and Warnock, R.G., 1976, Groundwater quality adjacent to a septic tank system: Journal of the American Water Works Association, v. 68, no. 11, part 1, p. 611-614.

Wilde, F.D., Radke, D.B., Gibs, J., and Iwatsubo, R.T., 1998, National field manual for the collection of water-quality data: U.S. Geological Survey Techniques of Water-Resources Investigations, book 9, chap. A1-A9.

Wilhelm, S.R., Schiff, S.L., and Cherry, J.A., 1994, Biogeochemical evolution of domestic waste water in septic systems, 1. Conceptual model: Ground Water, v. 32, no. 6, p. 905-916.

Zaugg, S.D., Smith, S.G., Schroeder, M.P., Barber, L.B., and Burkhardt, M.R., 2002, Methods of analysis by the U.S. Geological Survey National Water Quality LaboratoryDetermination of wastewater compounds by polystyrene-divinylbenzene solid-phase extraction and capillary-column gas chromatography/mass spectrometry: U.S. Geological Survey Water-Resources Investigations Report 01-4186, 37 p. 